\title{
Commentaries
}

\section{Bullying the public broadcaster: Threatening the ABC's role}

\section{QUENTIN DEMPSTER}

ABC Television

$\mathrm{P}$ UBLIC broadcasting in Australia has been under sustained attack for around 18 years now, both politically and through reduced funding. Although the Fraser Government (1975-1983) enacted legislation converting the $\mathrm{ABC}$ from the old broadcasting commission into a corporation (with its own borrowing and corporate treasury powers), the then Malcolm Fraser/Doug Anthony Liberal/National Coalition Government did not seem to hold more than the usual superficial grudges about our current affairs programmes' treatment of some of their practitioners. By that I mean their legislation - the $\mathrm{ABC}$ Act, establishing the new corporation, contained a key provision continuing the $\mathrm{ABC}$ 's structural and editorial independence from Government. The Act specifically states that the $\mathrm{ABC}$ board does not have to abide by Government policy, but merely must consider it in the formulation of $\mathrm{ABC}$ policies.

Even though the $\mathrm{ABC}$ is a creature of an Act of the Federal Parliament, that structural separation or independence has prevailed since 1983.

But, as we all know, there are many ways to skin a cat. In the ABC's case it is through stacking the $\mathrm{ABC}$ board with party political hacks in the finest tradition of Australian political cronyism and patronage. And more destructively through defunding. Since the publication of my book-Death Struggle: How political malice and boardroom powerplays are killing the $A B C$ - in 2000 , the ABC board has begun publishing a defunding graph in each annual report. In real terms the $\mathrm{ABC}$ 's operational base funding has been reduced by around 25 per cent since the peak years of 1985-86.

The $\mathrm{ABC}$ is no longer a big institution. In the last 13 years more than 2000 broadcasters and support staff have been made to walk the redundancy plank 


\section{THE PUBLIC RIGHT TO KNOW}

as the ABC's triennial funding submissions under the Hawke, Keating and now Howard governments have been flatly rejected. There is no long term strategy for public broadcasting as the current government has moved to digital transmission for the entire industry and pursues changes to the cross media and foreign ownership rules and the full privatisation of Telstra.

I won't recount all the instances of hostility that now characterise the $\mathrm{ABC}$ 's role in our national life and the public's thwarted expectations of just what an excellent and innovative comprehensive public broadcaster could and should provide. Just remember:

- The 1991 bias attacks on the ABC by executive government in Gulf War I when Bob Hawke took exception to the Middle East analyst Robert Springborg used on ABC current affairs;

- Gareth Evans' 1987 attempt to break the ABC up into core and non-core functions;

- The non-farm GDP funding deflator under both Bob Hawke and Paul Keating;

the ABC's own disastrous 1995 attempt to go commercial with consortium partners in pay television; the 1996 funding ambush by the newly elected Howard Government;

The 1997 vandalising of Radio Australia; the ongoing effort to destroy the $\mathrm{ABC}$ as a television production house;

- The 1997 forced sale of Australia Television, our satellite TV service to the Asia/Pacific;

The 2000 appointment of Jonathan Shier as managing director by the Donald McDonald/Michael Kroger board;

- The Howard/Costello Government's second rejection of the ABC board's triennial funding submission;

- The Richard Alston bias attack in Gulf War II.

The so-called ABC culture is not free from fault, of course. We are a flawed institution. There can be bias, error, imbalance, tastelessness, inexperience, careerism, editorial cowardice and self-censorship. We are all too aware of the ABC's deficiencies and faults, particularly its contemporary struggle under yet more funding pressure for quality and intellectual depth. But I contend that in the Australian media dominated by the tycoons Murdoch and Packer and their testicular hold on prime ministers and Labor/Liberal broadcasting and media policy, the $\mathrm{ABC}$ provides the crucial balance for our 
polity. Over these last 18 hostile years, through technology and the effort of the remaining broadcasters, the $\mathrm{ABC}$ has managed to retain what I call a mainstream audience in Australia - with around 16 per cent on our one television channel, Channel 2, and 22 per cent across our radio platforms - four networks: Radio National, ABC Classic FM, Triple J, NewsRadio, the nine metropolitan am stations and 48 regional stations.

For a very cost effective taxpayer investment $\mathrm{ABC}$ Online - our internet service - is an acknowledged success story with millions of hits and free downloads of specialist programme transcripts. Some lunkheads on the ABC board and in management now want to charge the public for these downloads. (Coincidentally the BBC has just decided to place all its programming archive on the net for free public access - with video streaming, a priceless gift and dividend for the contributions of generations of British licence payers). No such goodwill seems to exist within the board and management corridors at the ABC. Perhaps they should seek compatible work at Macquarie Bank rather than at a taxpayer-funded non-commercial public broadcaster.

ABC television's audience largely has been sustained through other broadcasters' programmes - mainly British. We're running UK TV on the ABC. It is cheaper to buy another broadcaster's shelf programmes than it is to make them yourself to sustain a viable prime time seven-days-a-week television schedule. Our ABC TV drama budget is around A $\$ 15$ million a year compared to $\$ 50$ million to $\$ 60$ million for each of Channels 7 and 9 under the legislated Australian content quota. There is no such Australian content quota imposed on the $\mathrm{ABC}$. We're in breach of our charter obligation to provide programmes which 'enhance a sense of national identity' but the board never formally acknowledges this: saying instead in annual reports to Parliament that we're creating Australian content to the 'extent possible' under funding constraints.

The Government-appointed ABC board under Donald McDonald, now seven years into what will be a ten-year chairmanship, never engages the public or even attempts to enlist its potentially very strong support in the battle for the ABC's survival ... even though the ABC Act sets out the duties of directors: to maintain and protect the independence and integrity of the ABC. We're still waiting for McDonald and his managing director, Russell Balding, to emerge from their comfort zones to effectively advocate for the ABC- to do more than go through the dignified bureaucratic motions, report and lettering writing.

I know all this sounds gloomy and depressing. I know the $\mathrm{ABC}$ redeems 
THE PUBLIC RIGHT TO KNOW

itself from time to time with some truly excellent pieces of journalism on news and current affairs programmes; some truly innovative satire like CNNNN; some spectacular and unwise interventions like Wil Anderson describing our old pal Richard Alston as a 'right wing pig rooter'; but my own chronic depression about the ABC comes from living with this political malice and history of hostility.

Of all the low blows administered to the $\mathrm{ABC}$ through funding pressure, the $\mathrm{ABC}$ board's recent removal of the cadet journalist intake must be about the lowest.

The board has also scrapped TV schools programming, including the student-friendly Behind the News. How does that sit with the board's stated criteria of re-balancing internal budgets to maintain our charter obligations. Broadcasting programmes of an educational nature is an operational base funding charter obligation.

When mass audience radio transmissions started in the late 1920 s, broadcasting was the hope of the world. Governments everywhere saw the new medium as a great force to educate, to nation build, to bring cohesion to society. But the hope was subverted by totalitarian communism in the Soviet Union; nazism in Germany; militarism in Japan with devastating consequences for the peoples of the world. Broadcasters can so easily be turned into propagandists.

In Australia, we fortunately followed the British model of Lord Reith's $\mathrm{BBC}$ - that independent public broadcasting in radio (and later television) should reflect middle class values of decency and accountability in public life. An institution like the $\mathrm{ABC}$ has contributed significantly to the evolution and robust effectiveness of Australian democracy over 71 years of the 103 years of federation.

The surviving non-commercial public broadcasters, of which is $\mathrm{ABC}$ is one, are under threat throughout the world - from the commercial interests of their media marketplace rivals and from governments which want to bend them to their will.

Given our recent domestic history there is no guarantee independent, comprehensive, non-commercial, mainstream and balancing public broadcasting will survive in Australia. News Corporation is currently insisting to the Howard Government that we should be reduced to the weak and sponsordependant voice of PBS in the United States. We're being urged to take advertising or go cap in hand to subscribers and sponsors through fund-raising telethons. We're being smeared by unsubstantiated claims of systemic bias. 
We're being strangled by inadequate funding.

Independent public broadcasters view their audiences as citizens in a democracy, not consumers in a marketplace. The public right to know, which underpins our human rights, is under threat while even a middle class, decent institution like the $\mathrm{ABC}$ is also under threat in Australia.

Quentin Dempster presents Stateline NSW on ABC TV. He is a former staffelected director of the $A B C$ board. His book Death Struggle, about political and funding pressure on the ABC (Allen and Unwin), was published in 2000. This was his address, 'Bullying the public broadcaster: Threatening the $A B C$ 's role on providing information and debate', at the third Public Right to Know (PR2K3) conference at the University of Technology, Sydney, 17-19 October 2003.

dempster.quentin@abc.net.au 